YEARBOOK

of ANTITRUST

and REGULATORY

STUDIES

www.yars.wz.uw.edu.pl
Peer-reviewed scientific periodical, focusing on legal and economic issues of antitrust and regulation. Creative Commons Attribution-No Derivative Works 3.0 Poland License.

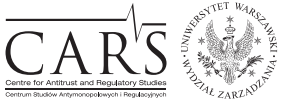

Centre for Antitrust and Regulatory Studies, University of Warsaw, Faculty of Management www.cars.wZ.uw.edu.pl

\title{
The Huawei Case and Its Aftermath: a New Test for a New Type of Abuse
}

by

\section{Sofia Oliveira Pais*}

\section{CONTENTS}

I. The Huawei case

II. The anti-competitive issues

III. The background: EU and national praxis

IV. A new test of abuse?

V. A glimpse at the solutions followed by the US and Japan

VI. The national judgments

VII. Conclusion

\begin{abstract}
Competition law sets limits on the exercise of intellectual property rights by dominant companies, namely in cases involving standard essential patents (SEPs). This article will examine the framework for SEP owners' right to seek an injunction, discussing competitive problems that such situations may cause as well as the solutions adopted by the European Institutions, comparing them with the US and Japanese approach, and finally reflecting upon the opportunity for a new test for a new type of abuse. Although the three legal orders - US, EU and Japan - apply different laws establishing a general presumption against injunctions in SEPs encumbered with FRAND commitments, their goal is the same: to protect the interest of the SEP holder to obtain a remuneration without an abusive recourse to injunctions. I will argue that, in the EU, the Huawei case created a new test for a new type of abuse, improving the comprehensibility and certainty for the companies involved in
\end{abstract}

* Professor of Law, Faculty of Law, Universidade Católica Portuguesa, Jean Monnet Chair, Coordinator of the Católica Research Centre for the Future of Law (Porto); sofiaopais@gmail. com. Article received: 27 February 2017; accepted: 26 April 2017. 
standardization across Europe and allowing the harmonization of national judicial solutions regarding the seeking of injunctions in the SEPs context. In spite of some uncertainties, the new test clarifies the role that competition rules should play in cases of abuses by SEPs owners.

\section{Resumé}

Le droit de la concurrence fixe des limites à l'exercice des droits de propriété intellectuelle par les entreprises dominantes, notamment dans les affaires concernant des brevets essentiels standard (standard essential patents, SEPs). Cet article examinera le cadre du droit des propriétaires de SEP de demander une injonction en discutant des problèmes de la concurrence que de telles situations peuvent causer ainsi que des solutions adoptées par les institutions européennes. Ces solutions seront ensuite comparées avec l'approche américaine et japonaise. Enfin, l'auteur réfléchira à l'opportunité d'un nouveau test pour un nouveau type d'abus. Bien que les trois ordres juridiques - les États-Unis, l'UE et le Japon - appliquent des lois différentes établissant une présomption générale contre les injonctions dans des SEP grevés d'engagements FRAND, leur objectif est le même: protéger l'intérêt du titulaire du SEP d'obtenir une rémunération sans recours abusif aux injonctions. Je soutiendrai que, dans l'UE, l'affaire Huawei a créé un nouveau test pour un nouveau type d'abus, améliorant la compréhensibilité et la certitude pour les entreprises impliquées dans la normalisation en Europe et permettant l'harmonisation de solutions judiciaires nationales concernant la recherche d'injonctions dans le contexte des SEP. Malgré quelques incertitudes, le nouveau test clarifie le rôle que les règles de la concurrence devraient jouer dans les cas d'abus par des propriétaires de SEP.

Key words: abuse of dominant position; FRAND commitments; seeking an injunction; standard essential patents; willing licensee.

JEL: K21

\section{The Huawei case}

Competition law sets increasingly stringent limits on the exercise of Intellectual Property Rights by dominant companies in cases involving Standard Essential Patents (SEPs). In this context, the Huawei $v$ ZTE case, concerning a patent dispute between two Chinese companies, may become a landmark judgment ${ }^{1}$. It is another case of patent wars in the EU, whereby a SEPs holder seeks an injunction to exclude potential licensees from the market.

1 CJ judgment of 16.06.2015, Case C-170/13 Huawei Technologies Co. Ltd. v ZTE, ECLI:EU:C:2015:477. 
Huawei is a Chinese telecommunications company which holds a European patent regarded as essential to the Long Term Evolution (hereinafter, LTE) standard developed by the standard-setting organization - European Telecommunications Standards Institute (hereinafter, ETSI) for fourth generation mobile phones. Huawei is a member of ETSI and had made a commitment to grant licenses to third parties on fair, reasonable and non-discriminatory terms (hereinafter, FRAND). Therefore, Huawei entered into negotiations with ZTE, a multinational mobile phone producer, for the conclusion of a licensing agreement on FRAND terms. However, those negotiations were not successful and Huawei brought an action for a patent infringement before a German court against ZTE, in order to obtain an injunction prohibiting the continuation of the infringement and an order for the rendering of accounts, the recall of products and the assessment of damages. ZTE claimed it was a willing licensee and that its competitor Huawei was abusing its dominant position by seeking injunctions. In the course of this dispute, the German Court referred several questions to the European Court of Justice (hereinafter, CJ) seeking to ascertain whether, and in which circumstances, an action for infringement, brought by a SEP owner encumbered with FRAND commitments against a manufacturer of products complying with that standard, represents an abuse of dominant position under EU competition law.

The CJ tried to clarify the limits of the SEP owner's right to seek an injunction prohibiting the alleged infringement of its patent by the prospective licensee, stating that the pursuit of an injunction against a potential willing licensee may amount to an abuse of a dominant position. The difficulties in reconciling this solution with the previous case law of the CJ regarding unilateral refusal to license raises the question of whether we are facing a new type of abuse and a new test for it.. This article will examine the framework for SEP owner's right to seek an injunction, referring the anti-competitive problems that such situation may raise and the solutions that have been pointed out by the European Commission and the Court of Justice, comparing them with the ones followed by the US and Japan. It will end shedding some light on the opportunity of a new test of abuse, after analysing some relevant national decisions taken after the Huawei judgment.

\section{The anti-competitive issues}

Although nowadays competition law and intellectual property law are considered complementary, as both seek innovation and growth ${ }^{2}$, there are

2 There is a large consensus nowadays between US and European antitrust agencies concerning the goals of competition law. Taking into account the lessons from Schumpeter, it is 
still certain areas of tension in which antitrust law should apply. Particularly relevant is the possibility to apply Article 102 TFEU to a SEP holder abusing its dominant position ${ }^{3}$, as it is discussed in the Huawei case.

In order to fully understand the antitrust concerns involved in SEPs licensing, it is necessary to recall the concepts of SEPs and standards as well as the benefits of standardization.

SEPs are patents that are essential to implement a specific industry standard. For example, it has been estimated (Italianer, 2015) that 100,000 patents are relevant to manufacture smartphones ${ }^{4}$. Therefore, products that comply with a certain standard cannot be manufactured without those patents.

generally accepted that competition law protects competition in order to promote efficiency and consumer welfare and that technical changes, strengthened by intellectual property rights, also promote efficiency and welfare gains. So the antitrust IP interface should find an equilibrium, allowing antitrust authorities to pursue anti-competitive practices without compromising innovation in the process. On this topic, cf. Lianos and Geradin, 2013, pp. 561-587; Greaves and Nasibyan, 2016, pp. 159-177; Jones and Sufrin, 2016, pp. 826-883; Hovenkamp, 2016, pp. 303-332 and also the US Department of Justice - Antitrust Enforcement and Intellectual Property Rights: Promoting Innovation and Competition, 2007. Retrieved from: https://www. ftc.gov/sites/default/files/documents/reports/antitrust-enforcement-and-intellectual-propertyrights-promoting-innovation-and-competition-report.s.department-justice-and-federal-tradecommission/p040101promotinginnovationandcompetitionrpt0704.pdf (1.05.2015).

3 The interface antitrust-IP can, therefore, raise certain concerns, as it is the case of "patent ambush" or "patent trolls". For the first scenery, see the Rambus case - COMP/C-3/38 636 Rambus - concerning intentional deceptive conduct, in the context of the standard-setting process; the company could commit an abuse by not disclosing the existence of the patents and subsequently claiming unreasonable royalties for the use of those relevant patents (although, in the Rambus case, Article 102 did not apply, as Rambus had low market power in the beginning of the standardization process); see also the similar case C-457/10 AstraZaneca v Commission, judgment of 6.12.2012, in which the Court held that misleading representation made by a dominant firm to patent offices in several Member States, in order to obtain the issue of Supplementary Protection Certificates to which they were not entitled, and deregistration of the (pharmaceutical products) marketing authorizations in several Member States, without justification, to prevent the appearance of competing generic drugs could constitute an abuse. On the other hand, "patent trolls" (also called "Patent Assertion Entities" or "Non Practicing Entities" (hereinafter, NPE) concern companies that do not manufacture products or are not engaged in research and development, but enforce patent rights against infringers; NPE became a source of litigation in the US, because it did not have the loser cost regime until Octane Fitness, LLC v ICON Health \& Fitness, Inc. and Highmark v Allcare Health, issued in 2014, in which the Supreme Court made the applicability of the loser pay for attorney costs easier if the lawsuit was considered baseless. In this article we will only address seeking an injunction by a SEPs holder under Article 102 TFEU.

4 The concept of "standard" depends on the context in which the term is used. Nevertheless, similar definitions have been adopted by the World Trade Organization (Technical Barriers to Trade Agreement, Annex 1-2), Standards Organization (ETSI) and European Institutions, such as the European Commission. In the EU, the concept given in Directive 98/34/EC of the European Parliament and the Council of 22 June 1998 (OJ L 2004, 21.7.1998, p. 37), laying down 
Standards can be approved by a Standard Setting Organisation or, in more rare situations, result from the market development shaped by consumer choices. Standards, as the former head of the European Commission's Directorate-General for Competition Directorate-General for Competition A. Italianer explains, form the basis of success of technology we take for granted - radio, cable-TV, Wi-Fi, computers, mobile phones, railroads, internet - being important to industry, manufacturers and consumers (Italianer, 2015).

The benefits of standardization are obvious, whether in terms of efficiency - reducing transaction and production costs, increasing efficiencies and reducing the level of uncertainty about the outcome of R\&D investment - or interoperability. In other words, compatibility among related products will allow systems and devices to interconnect through the same technology; hence, information, data and services can be exchanged among them and/or their users.

The EU has promoted standardization as a "tool for European competitiveness" 5 , as it enables consumers to switch more easily between products from different manufacturers and strengthens the integration of national markets in order to complete the internal market.

Standards may, however, raise antitrust concerns, particularly when competing technologies are eliminated in favour of the selected one. In this context, as Shapiro emphasized, in the beginning of the twenty-first century (Shapiro, 2001, pp. 119-150), involuntary infringement of patents might favour abusive conducts by the SEPs owners. In fact, the dominant firm owner of the patents essential to that standard may hold up manufacturers by imposing excessive royalties, or other abusive conditions, to the potential licensees (given the sunk cost supported by them) or even refuse to license the patent through an injunction against the infringer.

In order to address these concerns, standard-setting organizations (hereinafter, SSO) require SEPs owner to commit to license on FRAND terms. This commitment will assure SEPs holder an adequate remuneration and at the same time prevent the hold-up issue, giving all the market players access to a standard. In practice, FRAND commitments do not always avoid anti-competitive conducts by SEPs owners and competition law intervention might be necessary.

a procedure for the provision of information in the field of technical standards and regulations, as amended by Directive 2006/96/EC of 20.11 and Regulation 1025/2012 of 25.10 is particularly clear: "standard is a technical specification approved by a recognized standardization body for repeated or continuous application, with which compliance is not compulsory" (Article 1(4)); in addition, to these formal standards there are also de facto standards that arise in the market as a result of consumer choices or the conduct of a certain undertaking); it can promote interoperability and efficiency.

5 Commission Decision of 29.04.2014, Case AT.39939 - Samsung - Enforcement of UMTS standard essential patents, Brussels, C (2014) 2891 final, no. 22. 
The need for antitrust intervention is not, however, a consensual matter. While some authors (Geradin and Rato, 2007, pp. 101-161; Petrovčič, 2013, pp. 1363-1386) consider that only in rare situations will the standard-setting lead to exploitative abuse, others (Kobayashi and Wright, 2009, pp. 496-515) doubt the ability of competition laws to address this kind of concerns and with others suggest it would be preferable to apply Patent Law or Civil Law (Larouche and Zingales, 2014; Jones, 2014, p. 1 et seqq; Nihoul, 2015, p. 151 et seqq).

Nevertheless, antitrust agencies on both sides of the Atlantic agree that antitrust rules should apply when a dominant SEP owner requests an injunction against infringers of a FRAND-encumbered patent, as it might lead to anticompetitive abuses.

\section{The background: EU and national praxis}

The applicability of Article 102, or its equivalent in the national law, to SEPs holders seeking an injunction against infringers was addressed, in the beginning, by national courts, particularly by German ones. In 2009, the German Federal Court of Justice decided on the anti-competitive concerns of injunctions in the so-called "Orange Book Standard" case, which did not involve FRAND commitments. The Court stated that even before signing an agreement, companies have to behave as a licensee and pay royalties, at least into an escrow account, and provide regular account of those payments. On the other hand, the party seeking the license must make a binding, unconditional and reasonable offer for it. The German court applied the compulsory licence defence in a conservative way as it is considered an exception to the right of patent enforcement.

The test established by the German court was different from the one followed by the European Commission some years later, when the European institution issued decisions concerning seeking injunctions by dominant SEPs owners against infringers of FRAND encumbered patents. On the one hand, the Orange Book Standard test did not apply to SEP cases. On the other hand, the Commission's approach to these cases was more generous than the German Court's decision. For instance, it did not consider, as some lower German courts did, a potential licensee as an unwilling licensee if it challenged the validity or essentiality of the patent. It should be noticed, however, that some literature considers that the Commission exaggerated the consumers' marginal benefit of validity challenges to licensed SEPs ${ }^{6}$.

${ }^{6}$ In other words, economic analysis would not support the assumption of the European Commission. Therefore, if the outcome of discovering a few invalid patents in a licensed 
The first infringement decision adopted by the European Commission was the Motorola decision ${ }^{7}$. In this case, Motorola owned a SEP reading on the General Packet Radio Service (hereinafter, GPRS) standard (part of the 2G mobile telecom standard) and had committed to the ETSI to license it on FRAND terms and conditions. In April 2014, the Commission decided that a SEP owner's request of an injunction was an abuse and ordered Motorola to eliminate the negative effects of its conduct. The Commission found that in the exceptional circumstances of this case (the standard setting process and Motorola's commitment to license the SEP on FRAND terms) and in the absence of any objective justification (Apple was not unwilling to enter in a licence agreement on FRAND terms), Motorola had infringed Article 102 TFEU by seeking and enforcing an injunction against Apple before the Court of the Federal Republic of Germany.

The Commission strengthened the concern, already mentioned in 2012, in the Google/Motorola Mobility ${ }^{8}$ merger clearance, that the threat or the seeking of injunctions could be used to exclude competing products from the market or to impose burdensome licensing terms.

A fine was not imposed, however, by the Commission in this case as there were no previous decisions of the Commission or case-law of the Court in these matters and national decisions were divergent. Nevertheless, as the former Competition Commissioner Joaquin Almunia mentioned, the EU and the US "share the view that a FRAND commitment given in a standardization context means that the holder of standard-essential patents can no longer issue an injunction if the licensee is willing to negotiate a FRAND license" (Almunia, 2013).

In a similar case, concerning 3 G UMT (Universal Mobile Telecommunication System) SEPs, owned by the Samsung company ${ }^{9}$, the European Commission enforced the safe harbour test shaped in the Motorola case (outside this safe harbour, however, no more guidance was provided). The Commission in its Statement of Objections (issued in spite of Samsung's withdrawal of its injunction request as this had already caused harm) considered that under the specific circumstances where a commitment to license SEPs on FRAND terms had been given and where a potential licensee (in this case Apple) had shown

portfolio containing hundreds is to reduce royalties or delay, in a opportunistic way, the payment of those royalties, SEP owners' incentives to invest may decrease and harm consumers; see, Sidak, 2016, pp. 191-211.

7 Commission Decision of 29.04.2014, Case AT.39985 - Motorola - Enforcement of GPRS standard essential patents, Brussels, C(2014) 2892 final. See Angeli, 2015, p. 221 et seqq.

8 Commission Decision of 13.02.2012, Case No COMP/M.6381 - Google/Motorola Mobility, Brussels, C(2012) 1068.

9 Case AT.39939 - Samsung - Enforcement of UMTS standard essential patents, Brussels, C (2014) 2891 final. 
itself to be willing to negotiate a FRAND licence for the SEPs, recourse to injunctions harms competition, as it can exclude products from the market, harm consumers and hinder innovation.

A SEP holder is entitled to take reasonable steps to protect its interests by seeking preliminary and permanent injunctions against a potential licensee in, for example, the following scenarios: "(1) a potential licensee is in financial distress and unable to pay its debts; (2) a potential licensee's assets are located in jurisdictions that do not provide for adequate means of enforcement of damages; or (3) a potential licensee is unwilling to enter into a license agreement on FRAND terms"10. As such conditions were not met in the Samsung case (in fact, Apple made six offers including an unconditional licensing offer, deposited funds into an escrow account and agreed to let Motorola define the royalties subject to judicial review by German courts), the Commission informed Samsung that its injunctions could be an abuse of dominant position and Samsung offered commitments under Article 9 (proposed a specific licensing framework, and promised not to seek injunctions).

Several and pertinent doubts were cast by these two European Commission decisions: What is a willing licensee? Is it sufficient that the licensee merely declares its willingness or should the licensee act in accordance? Should the licensee make the first offer or is it enough to request an offer?

Some of these uncertainties were addressed by the Advocate General Melchior Wathelet and the Court of Justice in the Huawei case, concerning a Chinese Telecommunication company holding a European standard essential patent that sought injunctions against ZTE in the Dusseldorf Regional Court. The German Court referred to the Court of Justice several questions concerning the applicability of competition law to SEPs holder seeking an injunction against infringers of FRAND encumbered licences.

The Advocate General (hereinafter, AG) in his Opinion proposed a "middle path" and held the need to strike a balance between the right to intellectual property and the SEPowner's right of access to the courts, under Article 47 of the Charter of the Fundamental Rights of the EU and the freedom of companies implementing the standard to conduct business, protected by Article 16 of the Charter ${ }^{11}$. In addition, the AG enhanced the differences between the Orange Book Standard case and Huawei: while in the Huawei case a formal standard was adopted and FRAND commitments assumed, the

10 Cf. Press Release of 21.12.2012: Antitrust: Commission sends Statement of Objections to Samsung on potential misuse of mobile phone standard-essential patents. Retrieved from: http://europa.eu/rapid/press-release_IP-12-1448_en.htm (1.5.2016).

11 Opinion of Advocate General Wathelet, delivered on 20 November 2014, Case C-170/13 Huawei Technologies Co. Ltd v ZTE Corp., ZTE Deutschland GmbH, paras 52, 66. 
Orange Book Standard case concerned a de facto standard and no FRAND commitments were agreed.

It is an abuse, according to the AG, and it should be considered a solution of last resort, the fact that a holder of a SEP, which has given a commitment to grant third parties a licence on FRAND terms, has required an injunction or corrective measures where it is shown that the SEP holder has not honoured its commitment, even though the alleged infringer has shown itself to be objectively ready, willing and able to conclude such a licensing agreement. Before such last resort action is taken, the SEP holder has to alert the alleged infringer to that fact in writing, giving reasons and presenting a written offer of a license on FRAND terms with all the information and conditions usually established in that sector, particularly the precise amount of the royalty and the way in which that amount is calculated and if necessary request that the FRAND terms be fixed either by a court or by an arbitration tribunal.

In addition, it is legitimate for the SEP holder to ask the infringer either to provide a bank guarantee for the payment of royalties or to deposit a provisional sum at the court or arbitration tribunal in respect of its past and future use of the patent.

On the one hand, the infringer must respond to that offer in a diligent and serious manner: "if it does not accept the SEP holder's offer, it must promptly present to the latter, in writing, a reasonable counter-offer relating to the clauses with which it disagrees"12. On the other hand, an infringer's conduct cannot be regarded as dilatory if it can, during or after the negotiations, challenge the validity or essentiality of the patent ${ }^{13}$. With this solution the AG sets aside the rigid patent owner friendly approach by the German Court, which argued that the infringer must, even before concluding a licensing agreement, fulfil the obligations of the future licensing agreement.

\section{A new test of abuse?}

In the Huawei case, the Court followed the Opinion of the AG as well as the guidelines of the Commission. On July 16, 2015, the CJ issued a landmark judgment, recalling that an abuse of dominance will only exist in exceptional circumstances and that cases, like the Huawei case, are different from the ones concerning refusal to supply intellectual property rights ${ }^{14}$. In casu the Court considered as exceptional circumstances the fact that the patent was

\footnotetext{
12 AG Wathelet's opinion, para. 88.

13 Ibidem.

14 C-170/13 Huawei, paras 46-48.
} 
essential to a standard and that the SEP holder would have to license in FRAND terms. In these circumstances "a refusal by the proprietor of the SEP to grant a licence on those terms may, in principle, constitute an abuse within the meaning of Article 102 TFEU"15.

In other words, the Court held that the SEP holder does not abuse its dominant position in seeking an injunction, as long as "specific requirements" are complied with"16: (1) The SEP holder must "alert the alleged infringer of the infringement complained about by designating that SEP and specifying the way in which it has been infringed"17, as a party may not be aware of it; (2) The SEP holder must, taking into account the content of other licensing contracts, and guided by the principle of non-discrimination, present "a specific, written offer for a licence on FRAND terms", specifying, in particular, the amount of the royalty and the way in which that royalty is to be calculated ${ }^{18}$; (3) The alleged infringer must "respond to that offer in accordance with recognised commercial practices in the field and in good faith", without "delaying tactics" 19 . On the other hand, the Court also held that the alleged infringer "shall not be banned from challenging the validity, essential nature of the patents and /or their actual use" 20 .

Although, some doubts remain concerning the exact meaning of the "willingness test" or whether this decision can also apply to de facto standards, in the Huawei case the Court breaks new ground in this field and attempts to find an equilibrium between the interests of the SEP holder and the alleged infringer ${ }^{21}$. At the same time, the Court judgment allows the harmonization of national solutions, recognizing a "new test of abuse", supported by the European Commission praxis.

In fact, the European Commission, in both of its decisions - Motorola and Samsung 22 - relied on the overall framework of "wholly exceptional

15 C-170/13 Huawei, para. 53.

16 C-170/13 Huawei, para. 59.

17 C-170/13 Huawei, paras 60-62.

18 C-170/13 Huawei, paras 63-64. In addition, "parties may, by common agreement, request that the amount of the royalty be determined by an independent third party, by decision without delay" (C-170/13 Huawei, para. 68).

19 C-170/13 Huawei, para. 65.

${ }^{20} \mathrm{C}-170 / 13$ Huawei, para. 69. Pointing out that the ECJ ruling is "much closer to the reality of patent litigation and more practical than the German BGH's Orange Book-Standard" decision, see Körber, 2016.

21 Although this ruling achieved, as pointed out by Oliver and Bombois, 2016, a fair balance between the right of property established in article 17 of the Charter of Fundamental Rights of the EU and the right of access to the courts, provided in article 47 of the Charter, it still raises several doubts.

22 Cit. supra notes 7 and 12. 
circumstances" 23 to apparently introduce a new test of abuse: the willing licensee. Although compulsory licensing and potential abusive litigation tests were both invoked before the European institutions, they were not enforced and the willing licensee test took precedence.

Regarding compulsory licensing, it is a settled case law in the EU, that although a dominant company has "a special responsibility not to allow its conduct to impair competition on the common market" 24 , a refusal by a dominant firm to license IPRs cannot in itself constitute an abuse of a dominant position ${ }^{25}$. However, there are several exceptions to that rule, recognized by the CJ. Magill ${ }^{26}, I M S^{27}$ and Microsoft ${ }^{28}$ are just the most famous examples. In these cases, the Court held that the refusal to license IPRs to a competitor by a dominant firm is an abuse if it concerns an essential facility, such as copyright over weekly listings necessary to publish a broader television guide (Magill), or copyright over the 1860 brick structure, a system for collecting pharmaceutical sales data in Germany (IMS) or the interface information (Microsoft). In other words, a refusal must concern an input necessary to compete on a downstream market, preventing the appearance of a new product, the refusal is not objectively justified and the result is the elimination of competition.

In the Huawei case, the CJ stressed, endorsing the European Commission view in the Samsung and Motorola decisions, that the exceptional circumstances in SEPs cases are different from the ones found in the unilateral refusal to license judgments ${ }^{29}$ : the patent at stake is a SEP and the holder is prepared to grant licences on FRAND terms.

Furthermore, it has been invoked by Motorola, in the first Commission decision, as well as by certain authors (Vesterdorf, 2013, p. 109), that the abusive litigation test, established in ITT Promedia ${ }^{30}$ and Protégé Internationale ${ }^{31}$ cases, concerning proceedings related with unfair commercial practices and trademark oppositions, should also be considered in the SEPs context. In those

23 As the Court has highlighted in several cases, the list of exceptional circumstances is not exhaustive See infra cases: Magill, IMS and Microsoft cases, notes 26-28.

24 ECJ judgement of 9.11.1983, Case 322/81 Michelin, ECLI:EU:C:1983:313, para. 57.

25 ECJ judgment of 5.10.1988, Case 238/87 Volvo v Erik Veng, ECLI:EU:C:1988:477.

26 CJ judgment of 6.04.1995, joined cases C-241/91 P \& C-242/91 P Independent Television Publications Ltd (ITP) v Commission (Magill), ECLI:EU:C:1995:98.

27 CJ judgment of 29.04.2004, Case C-418/01 IMS Health v NDC Health, ECLI:EU:C:2004:257.

${ }^{28}$ CFI judgment of 17.09.2007, Case T-201/04 Microsoft $v$ Commission, ECLI:EU:T:2007:289.

29 C-170/13 Huawei, para. 48.

30 CFI judgment of 17.07.1998, Case T-111/96 ITT Promedia v Commission, ECLI:EU:T:1998:183.

31 CFI judgment of 13.09.2012, Case T-119/09 Protégé International v Commission, ECLI:EU:T:2012:421. 
cases, the Court held that bringing a judicial action is a fundamental right and it can only infringe competition rules in wholly exceptional circumstances: the action cannot reasonably be considered an attempt to establish rights and can therefore only serve to "harass the opposite party"; and is "conceived in the framework of a plan whose goal is to eliminate competition" 32 . Those criteria were not followed by the European institutions (European Commission and CJEU) in the SEPs cases. According to those institutions, restrictions on a dominant undertaking's right to enforce its IP in court may be ordered in the application of Article 102 TFEU, irrespective of the criteria used in ITT Promedia and Protégé International, as the standardization context and SEP holder commitment to license on FRAND terms and conditions would differentiate these cases from the above mentioned cases. The European Commission and the CJEU tend to see SEPs, when FRAND commitments were assumed, as special cases that need a special solution for the reasons outlined above. The willing licensee test would be, therefore, a new test ${ }^{33}$ applied to this new type of abuse.

According to the European institutions the willing licensee test will be determined on a case-by-case basis, taking into account specific facts. Certain guidance was provided by the European Commission in Motorola and Samsung decisions: willing licensees include "companies which, in case of dispute, are willing to have FRAND terms determined by a court or arbitrators (if agreed between the parties) and to be bound by such a determination" 34 . Outside this safe harbour no more guidance was provided.

The AG and the CJ, on the other hand, added in the Huawei case that the SEP holder, before seeking injunction, has to alert the alleged infringer to its intention in writing, giving reasons and presenting a written offer of a licence on FRAND terms with all the information and conditions usually established in that sector. If the infringer does not accept the SEP holder's offer, it must

32 T-111/96 ITT Promedia, para. 30.

33 This test has, however, been criticized, especially in the beginning, by its ambiguity. See Vesterdorf, 2013, p. 1; Vesterdorf, 2008, p. 109; Petit, 2013, p. 677 (tests of abuse that treat injunctions as a bargaining device "are economically inconsistent, and should thus be disregarded" and it would be problematic if agencies were ever to build theories of antitrust liability "on the basis of fictional economic assumptions"; in addition, the act of seeking an injunction, or the threat of so doing, "can induce potential licensees to accept unfair terms" - Petit, 2013, p. 42). Other authors argue that a "holistic standard", taking into account competition rules, as well as free movement and procedure rules, for limiting injunctions that are incompatible with EU law principles, would be better, see Graf, 2014, pp. 73-87.

${ }^{34}$ Cf., Antitrust decisions on standard essential patents (SEPs) - Motorola Mobility and Samsung Electronics - Frequently asked questions. Retrieved from: http://europa.eu/rapid/ press-release_MEMO-14-322_en.htm (1.05.2015). 
promptly present to the latter, in writing, a reasonable counter-offer relating to the clauses with which it disagrees.

In spite of the guidelines presented in this case, uncertainties remain, namely concerning the specificity of the licence offer and the timeframe for the potential licensee to request a licence. Is it possible, for example, for a potential licensee to know all the SEPs involved in the manufacturing of the product? Even if the SSO maintain a database of all SEPs, available to the public, is it reasonable to demand the potential licensee to know all the SEPs necessary to manufacture the product when some of the recent studies have shown that there might be billions of them? On the other hand, if we accept that the potential licensee needs to be proactive only after the dispute, as the Huawei judgment suggests, are we not burdening the SEPs owner and affecting the difficult equilibrium of the interests involved? Are we not rewarding the infringement of SEPs? What is the reasonable period of time for making the offer and the counter offer? How long can negotiations last before they are considered dilatory? What constitutes a FRAND offer? ${ }^{35}$ The Court has not solved those problems and the open solution given by the Advocate General - the time must be assessed in the light of the "commercial window of opportunity" available to the SEP holder for securing a return on its patent - does not favour legal certainty.

\section{A glimpse at the solutions followed by the US and Japan}

The doubts still remaining in the EU cases justify a quick look at the US and Japan solutions in this field.

In the US, antitrust concerns regarding SEPs can be addressed by Section 2 of the Sherman Act, similar to Article 102 TFEU, Section 5 of the Federal Trade Commission Act (FCTA) and by the Patent Act through an infringement action.

Section 2 of the Sherman Act prohibits "monopolization, attempts to monopolize, as well as conspiracy to monopolize any part of the trade or commerce between several States or with foreign nations". Concerning the SEP owner's market power, neither the EU nor the US establish a presumption

35 In fact, as pointed out by Grasso, 2016a, p. 213-238: "The ECJ ruling in Huawei and the right to seek injunctions based on FRAND-Encumbered SEPs under EU Competition Law: One step forward", this is a crucial issue and Huawei, Motorola and Samsung cases do not provide any guidance on the methodology that should be followed in order to determine the FRAND royalty rate. Some guidance might be provided by the European Commission's Horizontal Guidelines and practice (Grasso, 2016b, pp. 1-12, 5-12). 
of dominance for patent owners (as there is no economic justification for it; in fact, in certain cases the standard was not successful in the market or there were other standards in the market, or other non standardized products that could compete with the standard in casu). In certain cases, however, SEP ownership may confer market power, particularly when, in addition to the elimination of intra-standard competition as a consequence of the standardization process, there is also a restriction on the inter-standard competition ${ }^{36}$.

Regarding the use of the compulsory licensing test, the approach in the US is, nonetheless, slightly different. In the US context, after the uncertainty caused by apparently divergent solutions concerning refusal to license in Kodak (in this case, the Ninth Circuit considered that there was no valid justification for refusal to licence) ${ }^{37}$ and Xerox (in this case, the Federal Circuit accepted, apparently, a quasi-per se legality rule concerning the refusal to license) ${ }^{38}$ cases, the Supreme Court clarified the issue in the Trinko judgment ${ }^{39}$ and Aspen Skiing ${ }^{40}$. The Supreme Court held that under certain circumstances there is no duty to license. For example, a refusal to license is unlikely to constitute an act of monopolization when satisfying the request of rivals would require the dominant firm to share an input that is not indispensable, produce an input (or a combination of them) that it does not use, or enter in a new joint venture with its competitors.

Section 5 of FCTA can also apply to SEPs holder conduct. It prohibits "unfair methods of competition in or affecting commerce, and unfair or deceptive acts or practices in or affecting commerce". While this last prohibition is usually considered a consumer protection statute (for instance, it applies to misleading advertising), the first one may apply to anti-competitive conducts that are not

\footnotetext{
36 As it is well known, the Court defined dominant position, in the United Brands judgment, as a "position of economic strength which enables the undertaking to impede effective competition in a relevant market, by allowing it to behave substantially independently of competitors, customers, and consumers" (ECJ judgment of 14.02.1978, Case 27/76, ECLI:EU:C:1978:22, para. 65). In the US, the Supreme Court defined the monopoly power in U.S. v E.I. du Pont de Nemours \& Co., 351 U.S. 377, 391, as the "power to control prices or exclude competition". In spite of the differences (e.g. the acquisition of a dominant position is not prohibited in Article 102, but may be under US antitrust law), both jurisdictions refuse the presumption that the mere possession of a patent right confers market power. The assessment of that power will be made on a case-by-case basis. See the Horizontal Guidelines (HO 2011/C 11/1, 14.1.2011): market power can only be assessed on a case-by-case basis as there is no presumption that holding a SEP means the possession of a dominant position.

37 US Court of Appeals, Ninth Circuit, No. 96-16014, Image Technical Service Inc CPO v Eastman Kodak Co, February 27, 1998.

38 SCM Corp v Xerox Corp. 645 F2d. 1195 (2d Cir 1981).

39 Verizon Communications, Inc. v Law Offices of Curtis V. Trinko, LLP 540 US 398, 124 S.Ct. 872, 157 L.Ed.2d 823 (2004).

40 Aspen Skiing v Aspen Highlands Skiing, 472 U.S. 585 (1985).
} 
prohibited by the Sherman Act, such as invitation to collude (usually unilateral solicitations to enter into unlawful horizontal price-fixing or market allocation agreements) ${ }^{41}$.

In addition, in the United States, infringement actions are brought under the Patent Act in Federal District Courts. Since the US Supreme Court's decision in eBay, Inc. v MercExchange, L.L.C $C^{42}$, the Federal District Courts have the discretion to grant injunctions to stop patent infringement as long as the balance of traditional equitable factors, including a consideration of the public interest, weigh in favour of granting injunctive relief. Recently, two US Federal District Courts have applied the eBay factors (the plaintiff must demonstrate that it has suffered an irreparable injury; remedies available at law, such as monetary damages, are inadequate to compensate for that injury; considering the balance of hardships between the plaintiff and the defendant, a remedy in equity is warranted; and the public interest would not be disserved by a permanent injunction) to deny injunctive relief to holders of SEPs (Judge Robart in Microsoft v Motorola ${ }^{43}$ and Judge Posner in Apple $v$ Motorola $\left.{ }^{44}\right)$. It means that the patent owner cannot obtain an injunction, but rather must settle for damages only. Both cases are on appeal at the United States Court of Appeals for the Federal Circuit. Another US federal district court, however, came to a different conclusion. Judge Crabb in Apple $v$ Motorola $^{45}$ concluded that a FRAND commitment to an SSO, like any other contractual arrangement, does not deprive the SEP holder of the right to seek injunctive relief.

An alternative to Federal Court litigation is the filing with the US International Trade Commission (hereinafter, ITC) of a request for an order excluding imports of products that the ITC finds in violation of US patents. The ITC provides a second forum as long as the patentee can assert a patent infringement claim to stop the importation of infringing products. The ITC is required to issue an exclusion order upon the finding of a Section 337 violation (as long as the public interest does not favour another solution, in which case the US Trade Representative overturns the ITC order on public interest).

In this context, it is also important to refer that in January 2013 the US Justice Department (hereinafter, DOJ) and the US Patent and Trademark

${ }^{41}$ In fact, the FCT considered in the Rambus case (Rambus, Inc., No. 9302. FCT August 2, 2006) that the undertaking's conduct (patent ambush) was a standalone violation of section 5 (which was, however, later dismissed by the Court, without clarifying the scope of the provision).

42 Cf. eBay, Inc. v MercExchange, L.L.C, 547 US 388 (2006).

${ }^{43}$ Microsoft Corp. v Motorola, Inc. (Case No. 14-35393), US Court of Appeals for the Ninth Circuit (San Francisco).

44 Apple v Motorola, No. 1:11-cv-08540 (N.D. III, June 22, 2012).

45 Apple v Motorola, Fed. Cir. 2013 - 1150-1182. 
Office (hereinafter, PTO) jointly issued a Policy Statement on SEPs Subject to Voluntary FRAND Commitments ${ }^{46}$ in which the agencies explained that the remedy of an injunction or exclusion order may be inconsistent with the public interest, particularly in cases where an SEP owner has made a FRAND commitment to a standard setting body. The PTO-DOJ Statement noted, however, that an exclusion order may still be an appropriate remedy in some circumstances, such as where the putative licensee is unable or refuses to take a FRAND licence and is acting outside the scope of the patent holder's commitment to license on FRAND terms. In this context, the PTO-DOJ Statement identified a non-exhaustive list of relevant factors when determining whether public interest considerations should prevent the issuance of an exclusion order or when shaping such a remedy.

Finally, in two separate settlement agreements (which will therefore unlikely be used as precedents) in 2012 and 2013, the FTC required Motorola Mobility and Bosch GmbH not to seek injunctions on SEPs, except under limited circumstances enumerated by the FTC. The FTC also indicated that in appropriate circumstances, it might challenge SEP holders' efforts to obtain injunctions as "unfair methods of competition" in violation of Section 5 of the FTC Act ${ }^{47}$.

In Japan, antitrust concerns regarding SEPs can be addressed either by the Patent Act or the Civil Code. The Patent Act has provisions concerning compulsory licensing (for example Article 93), which are rarely used. In the case of standard essential patents, it has been argued, however, that the most likely scenario is the grant of compulsory (non-exclusive) licence for public interest (Kimura, 2012) ${ }^{48}$ by the Japan Patent Office Commissioner or the Minister of Economy, Trade and Industry.

Concerning the Japanese Civil Code, it is pointed out that Article 1 provides that "No abuse of rights is permitted". Courts "rarely restricted the patentee from exercising a right to seek an injunction by applying this provision on an abuse of rights" (Tonda, 2013). Article 1 can only apply as long as the exercise of the patent right is contrary to the purpose of the Patent Act (contribute to the development of industrial society) and is unacceptable in society in light of the circumstances of the case.

\footnotetext{
46 Retrieved from: http://www.justice.gov/atr/public/guidelines/ 290994.pdf (1.5.2016).

47 Retrieved from: http://www.ftc.gov/os/caselist/1210081/121126boschanalysis.pdf and from: http://www.ftc.gov/os/caselist/1210120/130103googlemotorolastmtofcomm.pdf. (1.05.2016).

48 No compulsory license has been granted until now; even when a standard is found necessary for the public interest, the product using the SEP may not be found necessary for the public interest.
} 
On January 23, 2014, the Japanese IP High Court announced that the Japanese Apple/Samsung FRAND case would be the matter of a Grand Panel and asked, for the first time, for public comments on the question whether there should be any restriction on the right to seek an injunction and damages based on a standard essential patent (SEP) in respect of which a FRAND declaration was made (58 Amicus Briefs were filed in response to the question $)^{49}$.

In this case, Samsung had sought a preliminary injunction against the importation and sale of certain models of Apple devices that allegedly infringed a standard-essential patent, subject to a FRAND obligation. In response, Apple filed an action seeking a declaration that its devices did not infringe a SEP, and that Samsung did not have a right to claim damages. In February 2013, the Tokyo District Court held that Samsung could not seek damages from Apple for the infringement of a SEP, due to Samsung's 'abuse of right'. The court rejected Samsung's argument that Apple was not willing to license as its offer reserved the right to contest validity and held: "There are no express provisions regarding the duties of parties at the stage of preparation for contract execution (...) it is reasonable to understand that, in certain cases, parties that have entered into contract negotiations owe a duty to each other under the principle of good faith to provide the other party with important information and to negotiate in good faith" 50 .

On May 16, 2014, the Grand Panel of the Intellectual Property High Court ruled that Samsung did not have a right to seek an injunction against Apple Japan concerning the SEP with FRAND commitments and modified the Tokyo District Court regarding damages ${ }^{51}$. It held that the enforcement of a FRAND pledged patent right - with a claim of damages - did not constitute an abuse of right if the amount of damages claimed was within the scope of the licence fee based on the FRAND condition. In other words, it is an abuse of monopoly, if a SEP holder seeks to obtain more damages than the ones that could have been obtained on FRAND terms, unless there are special reasons such as the alleged infringer not having any intent to take a FRAND license ${ }^{52}$.

To sum up, although US and Japan apply different laws, the goal is the same: protect the interests of the SEP owner, while avoiding abusive recourse to injunctions.

${ }^{49}$ Cf. http://www.worldipreview.com/article/japan-the-year-in-review (1.05.2016).

50 Apple Japan Limited Liability Company (Plaintiff) v Samsung Electronics Co., Ltd. (Defendant), Tokyo District Court/Judgment of Feb. 28, 2013/Case No. 2011 (wa) No. 38969; Case to seek declaration of non-existence of liability, 38 AIPPI J. 174 (2013).

51 Cf. http://www.ip.courts.go.jp/eng/hanrei/g_panel/index.html (1.05.2015).

52 Cf. http://www.ip.courts.go.jp/eng/ (1.05.2015). 


\section{National judgments}

In Europe, after the Huawei case, two German courts granted injunctions to SEP holders. On 3 November 2015, the Düsseldorf Regional Court granted injunctive relief to Sisvel, a SEP holder, against Haier, as it distributed UMTS and GPRS compatible mobile devices infringing Sisvel's SEP ${ }^{53}$. The German Court did not assess whether Sisvel's proposal was FRAND because the counteroffer did not meet Huawei's condition. In other words, the national court did not assess the initial offer and rejected the FRAND defence, because Haier did not provide an account and security for the payment of royalties and it had to take place within a month after the rejection of the counteroffer by the patent holder. The Higher Regional Court of Düsseldorf (appeals court) suspended, however, the enforcement of the injunction. It found that the lower court did not apply the Huawei standards correctly. The lower court had to decide whether Sisvel's offer was on FRAND terms, so it needed to determine the reasonableness of the royalty rate and other licence terms. It means that the alleged infringer is not required to propose a FRAND counteroffer if the offer received is not FRAND.

On 27 November 2015, the Regional Court Mannheim, in Saint Lawrence Communications $v$ Deutsche Telekom ${ }^{54}$, granted an injunction against Deutsche Telekom based on a European patent, which was found to be essential for the AMR-WB standard, relevant for wideband audio coding used in HD-Voice transmission. Saint Lawrence Communications, a European subsidiary of Acacia Research Group LLC, was the patentee. The products offered by Deutsche Telekom (DT) included mobile phones supplied by HTC and several other handset manufacturers, therefore, HTC and others participated in the proceedings as interveners in support of DT. The German Court assessed only the counteroffer and rejected the FRAND defence. It considered insufficient the counteroffer made by the HTC (supplier of the accused devices) ${ }^{55}$ as it did not specify the royalty rate (the royalties would have to be determined by the

53 Joined cases 4a O 93/14 and 4a O 144/14, summary retrieved from: www.eplawpatentblog. com/eplaw/2015/11/de-sisvel-v-qingdao-haier-group-first-german-injunction-after-cjeu- franddecision.html.

${ }^{54}$ Regional Court of Mannheim, case no. 2 O 106/14 - Saint Lawrence Communications $v$ Deutsche Telekom, summary retrieved from: eplaw.org/document/de-summary-mannheimdistrict-court/ (last visited 1.1.2017).

55 It must also be pointed out that, contrary to the CJ guidelines, Saint Lawrence first filed the action and then put Deutsche Telekom on notice. But, as Deutsche Telekom was unwilling to take a licence (it considered itself merely a distributor) and HTC waited over three months to indicate its willingness to license, that notice of infringement was not given too late. 
High Court of England and Wales) $)^{56}$. A Mannheim court, like the Düsseldorf Regional Court, required that the counteroffer was made on FRAND terms, even if the potential licensee was not contacted before the action was brought.

Both courts did not review the plaintiff's offer for FRAND compliance; they focused in the counteroffer. Thus, it seems that the burden of making a successful FRAND defence is still mainly on the defendant, according to the lower German courts. Fortunately, the Court of Appeals took into account the Huawei's judgment.

\section{Conclusion}

There is a general presumption against injunctions in SEPs encumbered with FRAND commitments, in the US, in the EU and in Japan. Although the laws applied may be different - patent and competition laws in the US, mainly civil law in Japan, and competition law in the EU (and these different approaches reflect different influences provided by different economic schools as well as different antitrust enforcement models) - the goal is the same: to protect the interests of the SEP holder to obtain a remuneration, while avoiding an abusive recourse to injunctions.

In the European context the national approaches to patents and SEPs holders seeking injunctions against infringers can also be quite different. Therefore, the Huawei case may have a significant impact, allowing the harmonization of national judicial solutions regarding the seeking of injunctions in the SEPs context. Furthermore, it can improve clarity and certainty for the companies involved (and for the industry in general) in standardization across Europe. In fact, the $\mathrm{CJ}$ endorsed the AG proposal as well as the European Commission decisions, setting a new test for a new type of abuse: the willing licensee. In spite of some uncertainties concerning the specificity of the licensing agreement offered by the defendant, or the time frame in which that agreement must be negotiated, the new test clarifies the role that competition rules should play in cases of abuses by SEPs owners.

\section{Literature}

Almunia, J. (2013). Abuse of dominance: a view from the EU. Speech presented at the Fordham's Competition Law Institute Annual Conference, New York, 27 September

56 C-170/13 Huawei, paras 66, 67. 
2013. Retrieved from: http://europa.eu/rapid/press-release_SPEECH-13-758_en.htm (1.05.2015).

Angeli, M. (2015). Willing to Define Willingness: The (Almost) Final Word on SEP-Based Injunctions in Light of Samsung and Motorola. Journal of European Competition Law \& Practice, 6(4), 221-241; https://doi.org/10.1093/jeclap/lpu122.

Geradin, D., Rato, M. (2007). Can Standard-Setting lead to exploitative abuse? A dissonant view on patent hold-up, royalty stacking and the meaning of FRAND. European Competition Journal, 3(1), 101-161.

Graf, T. (2014). National courts and EU regulators: institutional relations in the patent wars. Concurrences - New frontiers of antitrust, Bruylant, 73-87.

Grasso, R. (2016a). The ECJ ruling in Huawei and the right to seek injunctions based on FRAND encumbered SEPs under EU Competition Law: One step forward. World Competition, 39(2), 213-238.

Grasso, R. (2016b). Standard Essential Patents: Royalty Determination in the Supply Chain. Journal of European Competition Law \& Practice, 1-12, https://doi.org/10.1093/ jeclap/lpw089.

Greaves, R., Nasibyan, S. (2016). Exclusionary abuses: refusal to license intellectual property rights. In: S. O. Pais (ed.), Competition Law Challenges in the next decade (159-177). P.I.E. Peter Lang, http://dx.doi.org/10.3726/978-3-0352-6602-3.

Hovenkamp, H. (2016). Federal Antitrust Policy: The law of competition and its practice ( $5^{\text {th }}$ edition). West Academic Publishing.

Italianer, A. (2015). Shaken, not stirred. Competition Law Enforcement and Standard Essential Patents Retrieved from: http://ec.europa.eu/competition/speeches/text/ sp2015_03_en.pdf (1.5.2016).

Jones, A. (2014). Standard-essential patents: FRAND commitments, injunctions and the smartphone wars. European Competition Journal, 10(1), 1-36, http://dx.doi. org/10.5235/17441056.10.1.1

Jones, A., Sufrin, B. (2016). EU Competition Law, Text, Cases and Materials (6th edition). Oxford: Oxfird University Press.

Kimura, K. (2012). Use of the compulsory license system. IIP Bulletin, 21, 4. Retirevied from: http://www.iip.or.jp/e/e_summary/pdf/detail2011/e23_01.pdf (1.05.2016).

Kobayashi, B.H., Wright, J.H. (2009). Federalism, substantive preemption and limits on antitrust: an application to patent holdup. Journal of Competition Law \& Economics, 5(3), 496-515, https://doi.org/10.1093/joclec/nhp006.

Körber, T. (2016). Abuse of a dominant position by legal actions of owners of standardessential patents: Huawei Technologies Co. Ltd v ZTE Corp. Common Market Law Review, 53(4), 1107-1120.

Larouche, P., Zingales, N. (2014). Injunctive relief in disputes related to standard essential patents: time for the CJEU to set fair and reasonable presumptions. Tilburg Law and Economics Center (TILEC), Discussion Paper, DP 2014-048.

Lianos, I., Geradin, D. (2013). Handbook on European Competition Law - Substantive aspects. Cheltenham, UK, Northampton, USA: Edward Elgar Publishing.

Nihoul, P. (2015). Injunctions on Standard Essential Patents: In Search of a 'Clear Bright Line'. Journal of European Competition Law \& Practice, 6(3), 151-152, https://doi. org/10.1093/jeclap/lpv002.

Oliver, P., Bombois, T. (2016). Competition and Fundamental Rights. Journal of European Competition law \& Practice, 6(8), 598-608, https://doi.org/10.1093/jeclap/lpv047. 
Petit, N. (2013). Injunctions for FRAND-pledged SEPs: the quest for an appropriate test of abuse under article 102. European Competition Journal, 9(3), 677-719, http://dx.do. org/ 10.5235/17441056.9.3.677.

Petrovčič, U. (2013). Patent Hold-up and the limits of competition law: a transatlantic perspective. Common Market Law Review, 50(5), 1363-1386.

Shapiro, C. (2001). Navigating the Patent Thicket: Cross licenses, patent pools and standard settings. In: A.B. Jaffe, J. Lerner and S. Stern (ed.), Innovation Policy and the Economy (vol. 1, pp. 119-150). Cambridge, Massachusetts: MIT Press.

Sidak, J.G. (2016). Evading portfolio royalties for standard-essential patents through validity challenges. World Competition, 39, 191-211.

Tonda, T. (2013). Interpretation of Claim in Determining Patentability. IIP Bulletin, 22, 1-8. Retrieved from: http://www.iip.or.jp/e/e_summary/pdf/detail2012/e24_08.pdf (1.05.2016).

Vesterdorf, B. (2008). Article 82: Where do we stand after the Microsoft judgement?, Global Antitrust Review, 1.

Vesterdorf, Bo. (2013). Editorial - IP Rights and Competition Law Enforcement Questions. Journal of European Competition Law \& Practice, 4(2), 109-111, https://doi.org/10.1093/ jeclap/lpt005. 